\title{
Potential of Activated Carbon Derived from Local Common Reed in the Refining of Raw Cane Sugar
}

\author{
Ibrahim D-Abdullah ${ }^{1}$, Badie S. Girgis ${ }^{\wedge}, 2$, Yassin M. Tmerek ${ }^{3}$ and Elsaid H. Badawy ${ }^{4}$ \\ ${ }^{1}$ Sugar and Integrated Industries, Hawamdyah, 6 October \\ ${ }^{2}$ National Research Dokki, Giza, Egypt \\ ${ }^{3}$ Faculty of Science, Assiut University, Assiut, Egypt \\ ${ }^{4}$ Delta Sugar Company, Elhamoul, Kafr Elsheikh, Egypt \\ ‘e-mail: girgisbs@hotmail.com \\ (Received July 26, 2010; Accepted August 30, 2010)
}

\begin{abstract}
Common reed (Fragmites australis), a local invasive grass, was investigated as a possible feedstock for the production of activated carbon. Dried crushed stems were subjected to impregnation with phosphoric acid (30,40 and 50\%) followed by pyrolysis at $400 \sim 500^{\circ} \mathrm{C}$ with final washing and drying. Obtained carbons were characterized by determining: carbon yield, ash content, slurry $\mathrm{pH}$, textural properties and capacity to remove color bodies from factory-grade sugar liquor. Produced carbons possessed surface area up to $700 \mathrm{~m}^{2} / \mathrm{g}$, total pore volumes up to $0.37 \mathrm{~cm}^{3} / \mathrm{g}$, and proved to be microporous in nature. Decolorization of hot sugar liquor at $80^{\circ} \mathrm{C}$ showed degrees of color removal of 60 up to $77 \%$ from initial color of 1100 $1300 \mathrm{ICU}$, at a carbon dose of $1.0 \mathrm{~g} / 100 \mathrm{ml}$ liquor. No correlation seems to hold between synthesis conditions and \% R but depends on the degree of microporosity. A commercial activated carbon $\mathrm{N}$ showed a comparative better color removal capacity of $91 \%$. Common reed proved to be a viable carbon precursor for production of good adsorbing carbon suitable for decolorization in the sugar industry, as well as in other environmental remediation processes.
\end{abstract}

Keywords : Activated carbon, Porosity, Sugar refining

\section{Introduction}

Color is one of the most important quality criteria for sugar, the smaller the color values the higher the quality of the sugar. Color or colorants in sugar are of different origin; there are those derived from the plant (natural colorants) and those which are formed during processing (factory colorants). The natural colorants are: the chlorophyll ( $\mathrm{a}$ and b), carotenes, xanthophylls and flavonoids (further break down into anthocyanes), as these are present in the sugar cane plant and arrive in the raw juice after extraction. Other "colorless" components (color precursors) include two main groups (polyphenols, amino compounds) [1].

On the other hand, the sugar processing colorants (or factory colorants) are reaction products between the different colorless precursors and are distinguished into four groups: melanines, melanoidines, caramels and hexose alkaline degradation products (HADP) [2].

Despite observing all the rules of avoiding color formation and assuming best practices not to generate any unnecessary color, colorants are present and conditions prevail for generating color during processing. Particularly in cane sugar factories the regular process is not able for removing sufficiently color precursors towards obtaining white sugar directly as finished product. Most of the sugar plant pigments are removed during sugar factory operations. Sugar processing colorants, however, end up in the finished product raw sugar and require the refining process for removing these colorants. There are two classical chemical syrup clarification systems in the refining industry which have different effects on decolorization and been modified over time [1]. Phosphatation, which is using milk of lime and phosphoric acid and is a flotation process (floating scum), and carbonation, uses milk of lime and carbon dioxide gas forming a precipitating mud. The color removing efficiency varies to a great extent, phosphatation achieves 23 to $32 \%$ whereas carbonation 57 to $60 \%$ [3].

A different approach is ultra filtration [4], fairly newly introduced into the industry. By selecting suitable membrane types, colorants and polysaccharides are removed from sugar melt. However, it is still not yet possible achieving by this method decolorization rates of 77 to $91 \%[5,6]$ required for crystallization of high quality (low color) refined sugar without further additional decolorization steps [7,8].

The classical removal of colorants by affination and clarification is insufficient for bringing the fine liquor color down for refined sugar decolorization. An additional decolorization by an adsorption processing step becomes necessary. Traditionally in use are bone charcoal and granular activated carbon (GAC), a flexible alternative is powdered 
activated carbon (PAC), which is a "throw-away" decolorant [9] other than granular products [10], which are thermally regenerated. Activated carbons are known since many decades to possess a high adsorption capacity because of its extended internal porosity. In addition to its efficiency for removal of gaseous odours, it exhibits also distinguished power for removal of odorous, colored and noxious solutes from the liquid phase. Decolorization of sugar syrup in the last stage before crystallization, is a well established process since around two centuries. Bone char has been currently in use in many sugar refineries for ages. Activated carbon replaced bone char in most sugar production plants due to its higher removal capacity.

Activated carbon was traditionally produced from three main sources: coal, wood and coconut shells [11]. However as these are not economically available in all countries, it became necessary to utilize abundant raw materials with high carbon content, as suitable sources for its production. The high cost of imported decolorizing activated carbon dictated the search for locally alternative low- cost feasible feed stocks for porous carbon production. This directed attention to a large number of agricultural by- products that are copious, regenerable waste materials. Among the most effective and commercially viable sources were found to be fruit pits (date, apricot, olive peach) [11-15], nut shells (hazel, almond, walnut, peanut, black and English walnut, macadamia and pecan nuts) [16,17], woods [18-21], cotton stalks [22,23], rice straw and husks, water hyacinth [24,25], bagasse [26], corn cobs [27] and giant reed (Arundo donax) [28].

For the production of good adsorbing carbons several activation schemes were devised and applied along the years; these are broadly divided into either physical (thermal) or chemical procedures [11]. During the last few decades, chemical activation with phosphoric acid proved to be an economically feasible as it involves a single thermal treatment process (pyrolysis/activation), tailors the properties of activated products, achieved at relatively low treatment temperatures $\left(400 \sim 600^{\circ} \mathrm{C}\right)$, results in a high carbon yield $(35 \sim 50 \%)$, and most unreacted activant was economically recovered $[29,30]$. The process was observed to be suitable for a large number of ligno-cellulosic materials as reported earlier [11-17,19-26,29,30].

Common reed (Fragmites australis) is a widely spread grass, especially in North Delta, Egypt, growing as an aggressive and invasive plant around the lakes, ponds and river shores and canals. Presently, it finds no economically important utilization schemes as foodstuff or animal feeding. Thus its conversion into a product of practical use, such as activated carbon, would become desirable. In addition, its application in an industrially important process, that is decolorization of raw sugar, raises its value as it finds a direct use. Probably it might partially replace imported activated carbon in this field of application as well as in other environmental remediation schemes. This will open an unexploited field of utilization not investigated earlier, particularly in our country. It is a value-added material with economic value. Characterization of the developed carbon with respect to its surface area and porosity will be complimented by assessing its decolorization capacity for a factory- grade colored sugar syrup under simulated process conditions.

\section{Experimental}

\subsection{Activated carbons (ACs)}

These were obtained from the hand-picked stems of local common reed (Fragmites australis) collected from around the Brolus Lake in North Delta, Egypt. The reeds were sun and air dried, cut into short pieces, crushed to coarse grains, and used in next treatments. $100 \mathrm{~g}$ of the dried reed granules were soaked in one liter of $\mathrm{H}_{3} \mathrm{PO}_{4}$ of varying concentrations (30, 40 or $50 \mathrm{v} / \mathrm{v} \%)$, slightly shaken, left in contact overnight, and then separated by decantation. The impregnated reeds were transferred to a stainless steel box to fit inside the ignition chamber of an automatic controlled muffle furnace and temperature raised slowly to soak limit of 400, 450 or $500^{\circ} \mathrm{C}$ with a heating rate of $10^{\circ} \mathrm{C} / \mathrm{min}$ under its own atmosphere. Pyrolysis was continued for $3 \mathrm{~h}$ at each temperature, furnace cooled to ambient, and pyrolyzed mass was subjected to washing with hot water until washing water attained $\mathrm{pH} \sim 6.5$. Washed product, activated nine carbons, were dried in air oven at $110^{\circ} \mathrm{C}$ till constant weight. Derived activated carbons were analyzed for: carbon yield, ash content and slurry $\mathrm{pH}$ (Table 1 ).

\subsection{Characterization of porosity}

This was determined by the standard low temperature $\mathrm{N}_{2}$ adsorption at $77 \mathrm{~K}$, recorded by a Sorptometer of the Type NOVA 3000 (Quantachrome Corp). Obtained adsorption isotherms (Fig. 1) were subjected to the IUPAC recommended analysis in comparison to a non porous carbon, as described by the $\alpha_{\mathrm{s}}$ - plot [31]. Standard data for $\alpha_{\mathrm{s}}$-values were reported by Selles-Perez and Martin-Martinez [32]. Tested carbon adsorption data $\left(\mathrm{V}_{\mathrm{a}}, \mathrm{cm}^{3} / \mathrm{g}\right)$ were, thus, plotted against the $\alpha_{\mathrm{s}^{-}}$ values on reference material at the corresponding $\mathrm{P} / \mathrm{P}^{\mathrm{o}}$ (Fig. 2). Three texture parameters could be obtained from the $\alpha_{\mathrm{s}^{-}}$ plots: (1) the total surface area SA $\left(\mathrm{S}_{\mathrm{t}}^{\alpha}\right)$ from slope of the first linear section connecting the adsorption points to origin, (2) the non-microporous surface area SA $\left(\mathrm{S}^{\alpha}{ }_{n}\right)$ from slope of the rectilinear section connecting the later points (at $\left.\alpha_{\mathrm{s}} 1.0\right)$ and (3) the micropore volume $\left(\mathrm{V}^{\alpha}{ }_{\mathrm{o}}\right)$ from intersection of the latter line extrapolated to meet the $\mathrm{V}_{\mathrm{a}}$-axis (converted into $\mathrm{cm}^{3}$ of liquid nitrogen). Total pore volume $\left(\mathrm{V}_{\mathrm{p}}\right)$ is currently obtained from volume of nitrogen adsorbed at $\mathrm{P} / \mathrm{P}^{\mathrm{o}}=0.95$; also converted into $\mathrm{cm}^{3} / \mathrm{g}$. Two other parameters are deduced: microporous $\mathrm{SA}=\mathrm{S}_{{ }_{\mathrm{t}}}{ }-\mathrm{S}_{\mathrm{n}}{ }_{\mathrm{n}}$, and mesoporous $\mathrm{PV}=\mathrm{V}_{\mathrm{p}}-\mathrm{V}^{\alpha}{ }_{\mathrm{o}}$, 
Table 1. Description of Prepared Activated Carbons

\begin{tabular}{cccccc}
\hline \multicolumn{2}{c}{ Conditions of preparation } & Notation & \% Yield & \% Ash & Slurry pH \\
\hline$\% \mathrm{H}_{3} \mathrm{PO}_{4}$ & $\mathrm{HTT}$ & & & & \\
\hline \multirow{2}{*}{$30 \%$} & $400^{\circ} \mathrm{C}$ & $\mathrm{CR} \mathrm{340}$ & 44.2 & 8.3 & 4.6 \\
& $450^{\circ} \mathrm{C}$ & $\mathrm{CR} \mathrm{345}$ & 42.8 & 9.6 & 4.1 \\
& $500^{\circ} \mathrm{C}$ & $\mathrm{CR} \mathrm{350}$ & 44.2 & 10.6 & 4.4 \\
\hline \multirow{2}{*}{$40 \%$} & $400^{\circ} \mathrm{C}$ & $\mathrm{CR} \mathrm{440}$ & 45.0 & 9.4 & 4.1 \\
& $450^{\circ} \mathrm{C}$ & $\mathrm{CR} \mathrm{445}$ & 42.5 & 10.3 & 4.0 \\
$50 \%$ & $500^{\circ} \mathrm{C}$ & $\mathrm{CR} \mathrm{450}$ & 46.7 & 7.7 & 4.0 \\
& $400^{\circ} \mathrm{C}$ & $\mathrm{CR} \mathrm{540}$ & 45.4 & 4.0 \\
& $450^{\circ} \mathrm{C}$ & $\mathrm{CR} \mathrm{545}$ & 44.7 & 9.3 & 3.8 \\
\end{tabular}

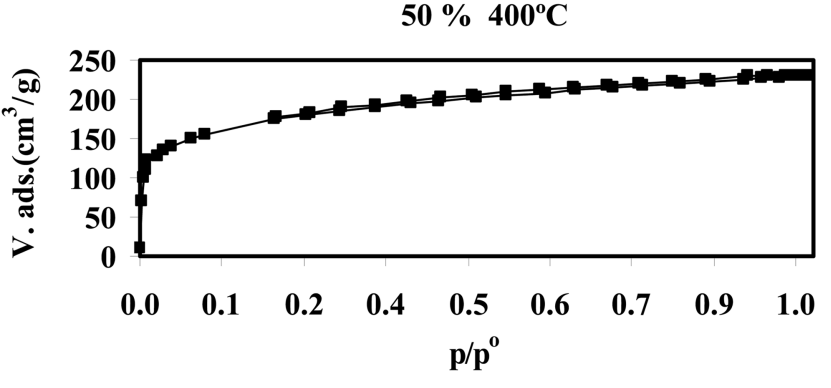

(a)

$50 \% 450^{\circ} \mathrm{C}$

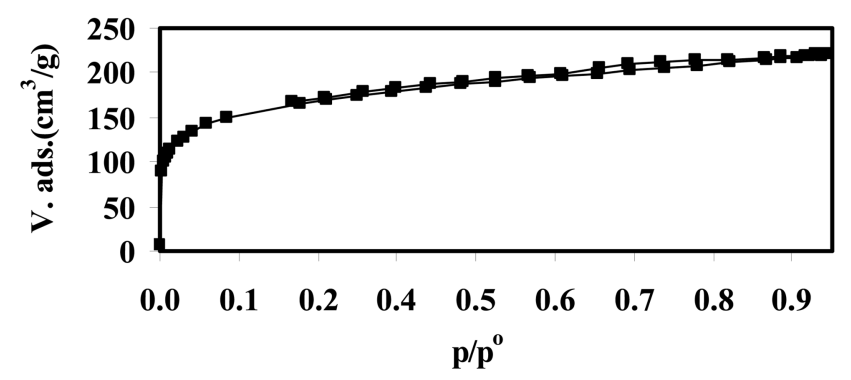

(b)

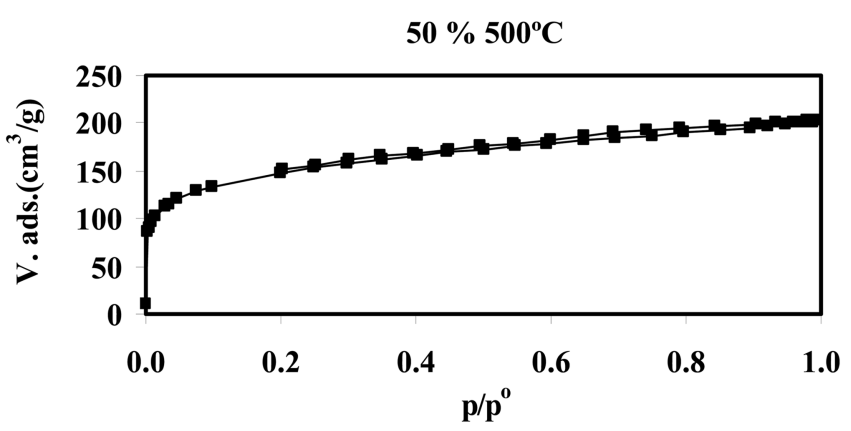

(c)

Fig. 1. $\mathrm{N}_{2}$ Representative adsorption isotherms on ACs prepared by impregnation with $50 \% \mathrm{H}_{3} \mathrm{PO}_{4}$.

and average pore diameter from $\bar{d}=\frac{\left(4 \times 10^{4}\right) V_{p}}{S_{B E T}}$ (in $\AA$ ).
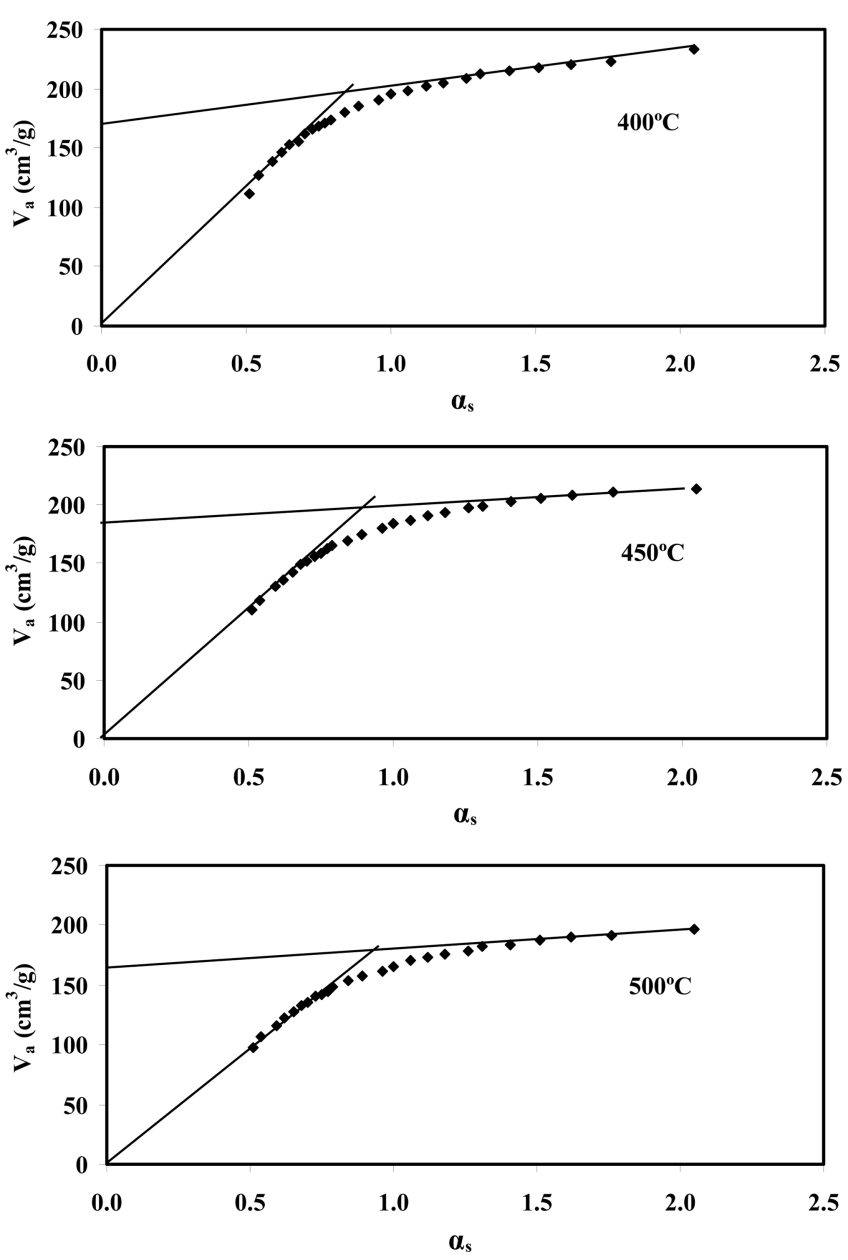

Fig. 2. Representative $\alpha_{s}$ - plots for $\mathrm{N}_{2}$ adsorption onto ACs impregnated with $50 \% \mathrm{H}_{3} \mathrm{PO}_{4}$.

These are collected in Table 2.

\subsection{Decolorization capacity towards sugar liquor}

Bach experiments were performed because it needs small amounts of the adsorbent which was obtained as fine and 
Table 2. Porous Characteristics of Activated Carbons Evaluated from N2-adsorption at $77 \mathrm{~K}$

\begin{tabular}{|c|c|c|c|c|c|c|c|c|c|}
\hline Parameter & CR340 & CR345 & CR350 & CR440 & CR445 & CR450 & CR540 & CR545 & CR550 \\
\hline $\mathrm{S}_{\mathrm{t}}^{\alpha}\left(\mathrm{m}^{2} / \mathrm{g}\right)$ & 703 & 689 & 633 & 563 & 675 & 492 & 633 & 605 & 535 \\
\hline $\mathrm{S}^{\alpha}{ }_{\mathrm{n}}\left(\mathrm{m}^{2} / \mathrm{g}\right)$ & 42 & 42 & 56 & 28 & 25 & 25 & 34 & 35 & 45 \\
\hline $\mathrm{S}_{\mathrm{mi}}^{\alpha}\left(\mathrm{m}^{2} / \mathrm{g}\right)$ & 661 & 647 & 511 & 535 & 650 & 467 & 599 & 570 & 490 \\
\hline $\bar{d}(\AA)$ & 20.9 & 19.3 & 20.9 & 21.0 & 20.8 & 20.6 & 22.5 & 22.5 & 23.3 \\
\hline$V_{p}\left(\mathrm{~cm}^{3} / \mathrm{g}\right)$ & 0.368 & 0.332 & 0.332 & 0.296 & 0.352 & 0.254 & 0.357 & 0.34 & 0.312 \\
\hline $\mathrm{V}^{\alpha}{ }_{\mathrm{o}}\left(\mathrm{cm}^{3} / \mathrm{g}\right)$ & 0.319 & 0.288 & 0.28 & 0.249 & 0.300 & 0.218 & 0.296 & 0.274 & 0.249 \\
\hline $\mathrm{V}_{\text {meso }}\left(\mathrm{cm}^{3} / \mathrm{g}\right)$ & 0.049 & 0.044 & 0.052 & 0.047 & 0.054 & 0.035 & 0.059 & 0.064 & 0.063 \\
\hline $\mathrm{S}_{\mathrm{mi}} / \mathrm{S}_{\mathrm{t}}$ & 0.940 & 0.939 & 0.911 & 0.950 & 0.963 & 0.949 & 0.949 & 0.942 & 0.916 \\
\hline $\mathrm{V}_{\mathrm{mi}} / \mathrm{V}_{\mathrm{p}}$ & 0.867 & 0.868 & 0.843 & 0.842 & 0.847 & 0.862 & 0.832 & 0.818 & 0.804 \\
\hline
\end{tabular}

fragile particles. Single stoppered bottles were used where $100 \mathrm{ml}$ of colored (factory-grade) sugar syrup were mixed with successively increased weights from 0.1 up to $1.0 \mathrm{~g}$ of the pre-dried, powdered AC, and slurry immersed in a hot water bath at $80^{\circ} \mathrm{C}$. It was kept at this temperature for $15 \mathrm{~min}$, with constant stirring filtered, and color of the cooled treated sugar liquor was measured using a Dr. Lang Spectrophotometer LP2 at $\lambda \max$ of $420 \mathrm{~nm}$. The data are graphically presented either as residual color (in ICUMSA units), or percent removal $(\% \mathrm{R})$, as function of carbon dose (CD). Before each experiment the color intensity of stock syrup was measured before adding the adsorbent so as to obtain the degree of decolorization $(\% \mathrm{R})$.

\section{Results and Discussion}

\subsection{Physico-chemical and textural characteristics of acti- vated carbons}

Nine activated carbons are developed here under mild conditions of phosphoric acid concentrations of $30 \sim 50 \mathrm{v} / \mathrm{v} \%$ $(\% \mathrm{P})$ and heat treatment temperatures of $400 \sim 500^{\circ} \mathrm{C}$ (HTT). The process seems feasible, as previously treated with other plant by-products. It gives an activated carbon yield of 42.3
$46.7 \%$ with ash contents ranging between 8.3 and $10.6 \%$ (Table 1). The origin of such inorganic matter could be ascribed to: (a) the inherited parent CR plant minerals ( ash $=4.3 \%$ ), and (b) additional inorganic minerals accumulated through dehydration of the activant medium $\left(\mathrm{H}_{3} \mathrm{PO}_{4}\right)$ forming phosphate products (polyphosphates, as well as organic and inorganic phosphates). These are permeated in the intricate porosity, and some of them are not easily leached in the washing process. These compounds might explain the observed acidity character (slurry $\mathrm{pH}=4.6 \sim 3.6$ ) of these $\mathrm{H}_{3} \mathrm{PO}_{4}$-activated carbons, as recently postulated by Puziy et al. $[29,30]$.

Prepared carbons exhibit moderate textural properties (Table 2) with total surface areas $\mathrm{S}_{\mathrm{t}}{ }_{\text {of }} 492$ up to $703 \mathrm{~m}^{2} / \mathrm{g}$, total pore volumes $\left(\mathrm{V}_{\mathrm{p}}\right)$ of 0.254 up to $0.368 \mathrm{~cm}^{3} / \mathrm{g}$, and average pore diameters $(\bar{d}=19.3-23.3 \AA)$. They possess typically microporous character, as the evaluated external (or non-microporous) surface areas are only $25 \sim 56 \mathrm{~m}^{2} / \mathrm{g}$, thus constituting only about 5 to $8 \%$ of total surface area. An estimation of microporosity, with respect to surface area or pore volume, is given in the last two lines of Table 2 where it appears that the hereby derived activated carbons are essentially microporous. The degree of (or fractional) microporosity in surface area $\left(\mathrm{S}_{\mathrm{mic}} / \mathrm{S}^{\alpha}{ }_{\mathrm{t}}=0.911\right.$ to 0.963$)$ and in pore volume $\left(\mathrm{V}_{\text {mic }} / \mathrm{V}_{\mathrm{p}}=0.818\right.$ to 0.868$)$. Such microporous character is anticipated to provide moderate decolorizing power as will

Table 3. Adsorption Capacity of Iodine from Solution in Comparison to Surface Area from $\mathrm{N}_{2}$-adsorption

\begin{tabular}{ccccc}
\hline Notation & $\mathrm{S}_{\mathrm{t}}\left(\mathrm{m}^{2} / \mathrm{g}\right)$ & $\mathrm{I}_{\mathrm{no}}(\mathrm{mg} / \mathrm{g})$ & $\mathrm{S}_{\mathrm{I}}\left(\mathrm{m}^{2} / \mathrm{g}\right)$ & $\mathrm{SI} / \mathrm{S}_{\mathrm{N}}$ \\
\hline CR 340 & 703 & 653 & 619 & 0.88 \\
CR 345 & 689 & 632 & 599 & 0.87 \\
CR 350 & 633 & 632 & 599 & 0.94 \\
CR 440 & 563 & 606 & 574 & 1.02 \\
CR 445 & 675 & 681 & 645 & 0.95 \\
CR 450 & 492 & 540 & 511 & 1.04 \\
CR 540 & 633 & 685 & 649 & 1.02 \\
CR 545 & 605 & 597 & 566 & 93 \\
CR 550 & 535 & 508 & 481 & 0.9 \\
Mean & & & & 0.95
\end{tabular}


be presented in next section.

Table 3 collects the estimated iodine number $\left(I_{\text {no }}\right)$ currently mentioned in technical brochures of activated carbons. Determined values of $\mathrm{I}_{\text {no }}$ run parallel to the surface areas evaluated from the low-temperature $\mathrm{N}_{2}$-adsorption. Taking into consideration the established cross-sectional area of $\mathrm{I}_{2}$ to be $40 \AA^{2}$, the iodine numbers are converted into surface area accessible to iodine $\mathrm{S}_{\mathrm{I}}$ by multiplication with a factor of 0.948 . Their ratio to $\mathrm{N}_{2}$-SA are found to range between 0.9 up to 1.04 , which indicate that although iodine possess a small diameter $(\sim 10 \AA)$, part of the internal porosity $(\sim 10 \%)$ appears inaccessible to it. This might also implicate an expected difficulty of diffusion of the sugar colorants, with bulkier size, into the whole internal porosity of the derived activated carbons.

\subsection{Sugar liquor decolorization capacity by the activated carbons}

The decolorization experiments were performed under same standard conditions: bottles with $100 \mathrm{ml}$ of sugar liquor $(\mathrm{ICU}=1100 \sim 1360)$, temperature of $80^{\circ} \mathrm{C}$, contact time $=15 \mathrm{~min}$, and carbon dose $(\mathrm{CD})$ per bottle $=0.1 \mathrm{up}$ to $1.0 \mathrm{~g}$. Obtained data are presented as: (a) filtrate color in ICU, and (b) degree of color removal in percent $(\% \mathrm{R})$, as function of carbon dose (CD) (Figs. 3 and 4). A decolorizing carbon $(\mathrm{N})$, available in the factory, was tested under the same conditions for the sake of comparison. Table 3 gives
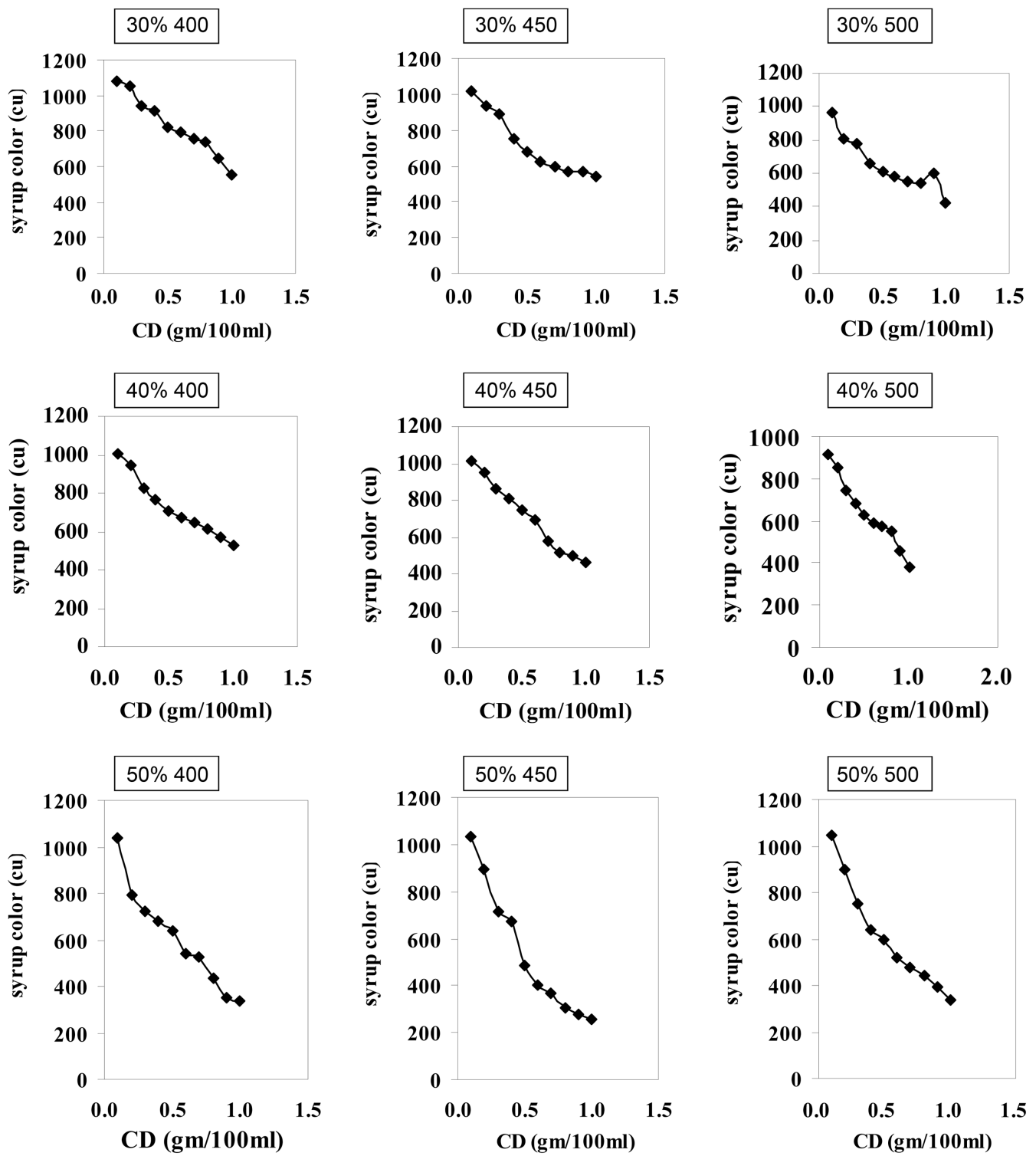

Fig. 3. Variation in liquor color (CU units) as function of carbon dose (CD) of the nine ACs. 

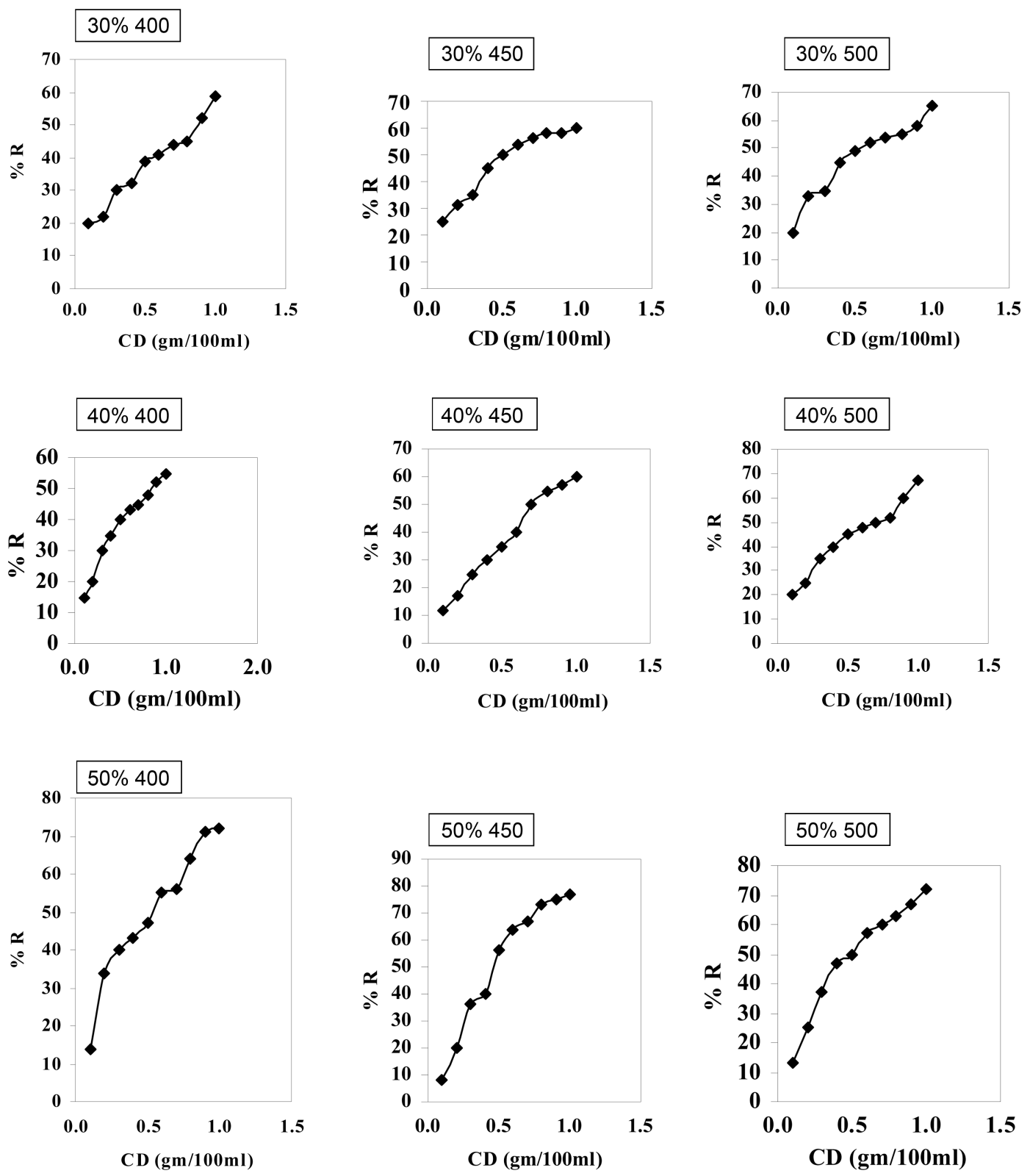

Fig. 4. Variation in color removal capacity $(\% R)$ as function of carbon dose $(C D)$ of the nine ACs.

collective data for the activated carbons at selected CD values, and compared to

$\mathrm{N}$ as relative color removal: $\% \operatorname{Rel}=\frac{\% R(C)}{\% R(N)}$;

Starting with factory-grade raw sugar syrup with color intensity of $1120 \sim 1360$ (ICU), we obtained a successive decrease in color (ICU), and increase in $\% \mathrm{R}$, as function of carbon dose mixed with the hot liquor. Optimum liquor color attained values (at maximum $\mathrm{CD}=1.0 \mathrm{~g}$ ) ranged between 553 and 252 ICU, corresponding to removal capacity of $\mathrm{R}=$ 55 up to $77 \%$. Such values appear to be much lower than decolorization by carbon $\mathrm{N}$ whose color appears at CD $1.0 \mathrm{~g}$ as 95 (ICU) and $\mathrm{R}=91 \%$. Relative color removal capacity of our carbons (Rel R) appears as 0.6 up to 0.84 , at the optimum carbon dose of $1.0 \mathrm{~g} / 100 \mathrm{ml}$. This might anticipate that in order to reach acceptable color around $100 \mathrm{ICU}$, and color removal of $90 \%$, higher carbon doses should be required. Interpolated values of $\mathrm{CD}$ to attain comparable values were estimated by approximate extrapolation, are found to vary from 1.52 up to $2.32 \mathrm{~g} / 100 \mathrm{ml}$. The lowest efficiency belong to carbon $40 / 400^{\circ} \mathrm{C}$, whereas the best decolorization carbon is the $\mathrm{CR} 50 / 450^{\circ} \mathrm{C}$, this is confirmed by Rel $\mathrm{R}=0.84$ and recommended $\mathrm{CD}$ of $1.5 \mathrm{~g} / 100 \mathrm{ml}$ (Table 4). Thus, a laboratory prepared activated carbon from 
Table 4. Comparative \%R of Activated Carbons as Compared to Commercial Decolorizing Carbon NORIT (Rel R)

\begin{tabular}{ccccccccccc}
\hline \multirow{2}{*}{ Notation } & \multicolumn{2}{c}{$0.1 \mathrm{~g} / 100 \mathrm{ml}$} & \multicolumn{2}{c}{$0.3 \mathrm{~g} / 100 \mathrm{ml}$} & \multicolumn{2}{c}{$0.5 \mathrm{~g} / 100 \mathrm{ml}$} & \multicolumn{2}{c}{$0.7 \mathrm{~g} / 100 \mathrm{ml}$} & \multicolumn{2}{c}{$/ 100 \mathrm{ml}$} \\
\cline { 2 - 10 } & $\% \mathrm{R}$ & $\mathrm{Rel} \mathrm{R}$ & $\% \mathrm{R}$ & $\mathrm{Rel} \mathrm{R}$ & $\% \mathrm{R}$ & $\mathrm{Rel} \mathrm{R}$ & $\% \mathrm{R}$ & $\mathrm{Rel} \mathrm{R}$ & $\% \mathrm{R}$ & $\mathrm{Rel} \mathrm{R}$ \\
\hline CR 340 & 20 & 0.30 & 30 & 0.36 & 39 & 0.46 & 44 & 0.50 & 59 & 0.65 \\
CR 345 & 25 & 0.38 & 35 & 0.42 & 50 & 0.59 & 56 & 0.63 & 60 & 0.66 \\
CR 350 & 20 & 0.30 & 35 & 0.42 & 49 & 0.58 & 54 & 0.61 & 65 & 0.71 \\
CR 440 & 15 & 0.23 & 30 & 0.36 & 40 & 0.47 & 45 & 0.51 & 55 & 0.60 \\
CR 445 & 12 & 0.18 & 25 & 0.30 & 35 & 0.41 & 50 & 0.57 & 60 & 0.66 \\
CR 450 & 20 & 0.30 & 35 & 0.42 & 45 & 0.53 & 50 & 0.57 & 67 & 0.73 \\
CR 540 & 13 & 0.20 & 40 & 0.49 & 47 & 0.55 & 56 & 0.63 & 72 & 0.79 \\
CR 545 & 8 & 0.11 & 36 & 0.44 & 57 & 0.67 & 67 & 0.76 & 77 & 0.84 \\
CR 550 & 13 & 0.20 & 38 & 0.46 & 50 & 0.59 & 60 & 0.68 & 72 & 0.79 \\
NORIT & 66 & & 82 & & 85 & & 88 & & 91 & \\
\hline
\end{tabular}

common reed by $50 \% \mathrm{P}\left(450^{\circ} \mathrm{C}\right)$ seem to be a promising decolorizing carbon useful in refining factory-colored sugar liquor to get acceptable refined sugar suitable for the next crystallization process.

\subsection{Impact of activation factors on the decolorizing power}

The two processing factors considered here were: the impregnant strength $\left(\mathrm{v} / \mathrm{v} \% \mathrm{H}_{3} \mathrm{PO}_{4}\right)$ and the heat treatment temperature (HTT). Their consequent effect on the decolorization capacity towards sugar liquor is important in order to optimize the conditions of preparation for this specific purpose and to assess the feasibility of local common reed as

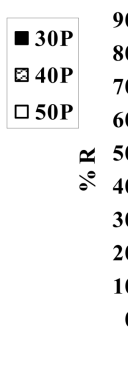

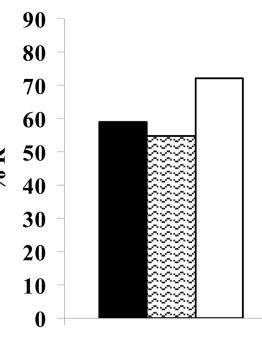

400

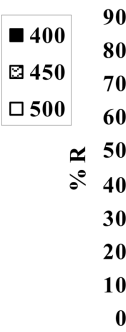

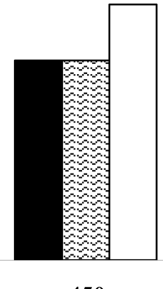

450

(a)

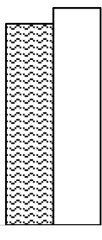

30

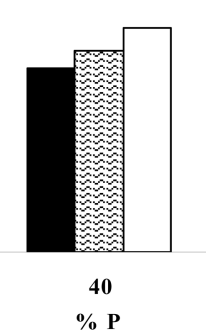

(b)
500

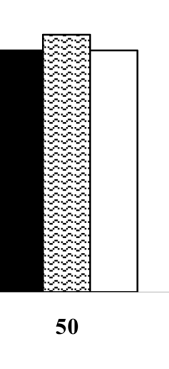

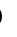

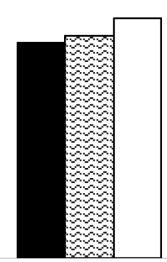

Fig. 5. Optimum decolorization capacity at $\mathrm{CD}=1.0 \mathrm{~g} / 100 \mathrm{ml}$ $(\% \mathrm{R})$ as function of processing conditions. a prospective raw material for production of adsorbing carbon. Fig. 5 displays a correlation between maximum decolorization capacity for sugar liquor and the two variables of carbon preparation. Thus, raising the HTT (Fig. 5(a)) seems to inflict very small promotion in $\% \mathrm{R}$, especially at 30 and $40 \% \mathrm{P}$. At the highest activant concentration of $50 \%$ $\mathrm{P}$, a temperature of $450^{\circ} \mathrm{C}$ appears as the most effective with $\% \mathrm{R}=77 \%$. On the other hand, Fig. 5(b) displays that raising the $\% \mathrm{P}$ enhances, generally, $\% \mathrm{R}$ the strong effect appears at $450^{\circ} \mathrm{C}$. Pyrolysis at $400^{\circ} \mathrm{C}$ does not show a regular effect on $\% \mathrm{R}$ whereas a drop followed by a raise at the highest activant concentration occurs. Generally, the color removal capacity for sugar liquor appears to be a function of $\% \mathrm{P}$, although a moderate HTT of $450^{\circ} \mathrm{C}$ seems to be appropriate.

\subsection{Comparison of decolorization capacity to the carbon - $N$}

In order to understand the cause of difference, Table (5) collects some characteristics of $\mathrm{C}-\mathrm{N}$ as compared to the best decolorizing carbon $\left(\mathrm{CR} 50 / 450^{\circ} \mathrm{C}\right)$. The most striking difference appears at the low carbon doses, between 0.1 and 0.5 , where the commercial carbon achieves distinguished decolorization capacity (from around 6 to 1.5 fold higher). At a maximum carbon dose of $1.0 \mathrm{~g} / 100 \mathrm{ml}$ liquor, the two

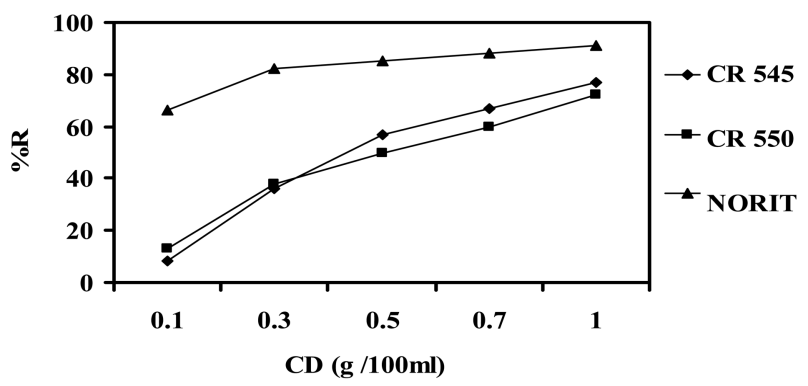

Fig. 6. Comparison of decolorization capacity (\%R) by NORIT - Carbon (N) and selected activated carbons as function of carbon dose (CD). 
carbons approach each other where the laboratory-prepared activated carbon AC attains $84 \%$ the capacity of carbon $\mathrm{N}$. Searching for the origin of this difference between the physico-chemical and textural properties reveals the following: (1) both carbons measured same total SA $\left(\sim 600 \mathrm{~m}^{2} / \mathrm{g}\right)$, however the external (or non-microporous) $\mathrm{SA}$ of $\mathrm{N}$ is around 5- times higher than carbon CR 50/450 (viz 165 and $35 \mathrm{~m}^{2} / \mathrm{g}$, respectively). Micropore $\mathrm{SA}$ and $\mathrm{PV}$ are much lower in carbon $\mathrm{N}$ (viz 448 and $570 \mathrm{~m}^{2} / \mathrm{g}$, and 0.218 and $0.274 \mathrm{~cm}^{3} / \mathrm{g}$ ) (3) degree of mesoporosity $\left(\mathrm{S}_{\mathrm{me}} / \mathrm{S}_{\mathrm{t}}\right.$ and $\left.\mathrm{V}_{\mathrm{me}} / \mathrm{V}_{\mathrm{p}}\right)$ is clearly higher in $\mathrm{N}$ than in (CR 50/450) viz 27 vs. 6 , and 48 vs. $19 \%$, respectively. It appears, thus that the developed mesoporosity character in the technical decolorizing carbon promote its color removal capacity, as an essential property for this process. Other properties may bring about minor effects, such as the low ash content and relatively higher slurry $\mathrm{pH}$ (Table 5). Extrapolation of the decolorization curves proved that to attain the commercial capacity, $1.5 \mathrm{~g} /$ $100 \mathrm{ml}$ liquor is needed to achieve the removal capacity of $\mathrm{N}$ (to reach an ICU of 100 , or $90 \%$ R) (Table 6). Nevertheless, this amount will over compensate by far the much higher price of the imported carbon, as the hereby derived product is locally obtained from a cheap copious undesirable feedstock under a cost-effective activation process.

Table 5. Comparison of Some Characteristics of Carbon-N to Those of Carbon $\left(50 \sim 450^{\circ} \mathrm{C}\right)$

\begin{tabular}{ccc}
\hline Property & CR 545 & C -N \\
\hline slurry pH & 3.80 & 4.60 \\
$\%$ ash & 10.3 & 5.3 \\
$\mathrm{~S}^{\alpha} / \mathrm{S}_{\mathrm{t}}(\%)$ & 6 & 27 \\
$\mathrm{~V}_{\text {mes }} / \mathrm{Vp}(\%)$ & 19 & 48 \\
$\mathrm{Vp}\left(\mathrm{cm}^{3}\right)$ & 0.338 & 0.416 \\
$\mathrm{~S}^{\alpha}{ }_{\mathrm{t}}\left(\mathrm{m}^{2} / \mathrm{g}\right)$ & 605 & 613 \\
$\mathrm{~S}^{\alpha}{ }_{\mathrm{n}}\left(\mathrm{m}^{2} / \mathrm{g}\right)$ & 35 & 165 \\
$\mathrm{~S}^{\alpha}{ }_{\text {mic }}\left(\mathrm{m}^{2} / \mathrm{g}\right)$ & 570 & 448 \\
$\mathrm{~V}^{\alpha}{ }_{\mathrm{o}}\left(\mathrm{cm}^{3} / \mathrm{g}\right)$ & 0.274 & 0.218 \\
$\mathrm{~V}_{\text {meso }}\left(\mathrm{cm}^{3} / \mathrm{g}\right)$ & 0.064 & 0.198 \\
$\bar{d}(\AA)$ & 24.4 & 27.1 \\
\hline
\end{tabular}

\section{Conclusions}

Common reed (Fragmites australis), a local invasive grass, proved to be amenable to activation with $\mathrm{H}_{3} \mathrm{PO}_{4}$, as impregnant, with various concentrations, followed by pyrolysis at $400 \sim 500^{\circ} \mathrm{C}$ (HTT), for the production of good adsorbing carbons. Developed carbons were obtained with high yields (42.3 46.7\%), with good surface areas of 492 to $703 \mathrm{~m}^{2} / \mathrm{g}$ and internal porosity of 0.25 up to $0.37 \mathrm{~cm}^{3} / \mathrm{g}$. Essentially microporous carbons are formed where more than $80 \%$ of porosity occur. within this range of pore sizes. A practical evaluation of adsorption capacity was tested in the refining of factory-grade raw cane sugar with higher color intensity (1100 1300 International Color Units "ICU"). Common reed-derived activated carbons (CR-ACs) achieved color removals $(\% \mathrm{R})$ of 59 up to $77 \%$, and the best decolorants are those impregnated with $50 \mathrm{v} / \mathrm{v} \% \mathrm{H}_{3} \mathrm{PO}_{4}$ and carbonized at higher HTT. A commercial activated carbon (NORIT-N) was tested under same sugar refining conditions and exhibited a relatively higher decolorization capacity of 91\%. Probable causes of difference could be: a somewhat better developed mesoporosity of $\mathrm{N}$ than the CR-ACs, in addition to a lower ash content. An interpolated carbon dose, needed to attain equivalent removal capacities to $\mathrm{N}$, were found to range between 1.5 and $2.1 \mathrm{~g}$. This would overcompensate the much higher export price of carbon $\mathrm{N}$ in comparison to the laboratory-prepared CR-ACs obtained from an aggressive invasive plant with an insignificant economic value. Overall, the present study is considered to be the first; concerning this plant source of negligible importance and its conversion into an economically valuable material with anticipated purposes.

\section{References}

[1] Chen, J. C. P. "Cane Sugar Technology", $11^{\text {th }}$ ed., Wiley Interscience Publications, John Wiley \& Sons Inc., USA, 1985.

[2] Mersad, A.; Lewandowski, R.; Heyd, B.; Decloux, M. ISJ

Table 6. Change in Liquor Properties at Decolorization with $1.0 \mathrm{~g} / 100 \mathrm{ml}$ Liquor, and Interpolated Carbon Doses to Attain ICU=100 or $90 \%$ Removal (R)

\begin{tabular}{|c|c|c|c|c|c|}
\hline \multirow{2}{*}{ Notation } & Slurry & initial liquor & final liquor & $\mathrm{CD}$ & $\mathrm{CD}$ \\
\hline & $\mathrm{pH}$ & $\mathrm{pH}$ & $\mathrm{pH}$ & at ICU $=100$ & at $\mathrm{R}=90 \%$ \\
\hline CR 340 & 4.63 & 7.00 & 6.00 & 1.69 & 2.14 \\
\hline CR 345 & 4.10 & 6.90 & 6.55 & 1.82 & 2.20 \\
\hline CR 350 & 4.40 & 7.36 & 6.35 & 1.71 & 2.10 \\
\hline CR 440 & 4.13 & 7.33 & 6.20 & 1.76 & 2.22 \\
\hline CR 445 & 4.05 & 7.34 & 6.15 & 1.92 & 1.90 \\
\hline CR 450 & 4.02 & 7.44 & 6.60 & 1.54 & 1.83 \\
\hline CR 540 & 4.00 & 7.19 & 5.90 & 1.58 & 1.62 \\
\hline CR 545 & 3.75 & 6.55 & 5.80 & 1.49 & 1.52 \\
\hline CR 550 & 3.64 & 7.00 & 5.83 & 1.74 & 1.68 \\
\hline
\end{tabular}


2003, 105, 269.

[3] Clark, M. A.; Blanco R. S.; Godshall, M. A. ISSCT 1986, 4, 670.

[4] Riffer, R. Proc. SIT 1997, 716 (A), 114.

[5] Tatoud, I.; Jacob, S.; Liou, J. K.; Bento, S. M.; Decloux, M. Proc. SIT 1998, 741 (B), 223.

[6] Decloux, M.; Tatoud, I.; Mersad, A. Zuckerind 2000, 125,106

[7] Lancrenon, X.; Herve, D.; Rousset, F. Proc. SIT 1998, 741 (B), 726 .

[8] Lancrenon, X. ISJ 2003, 105, 390.

[9] Baikow, V. E. "Manufacture and refining of raw cane sugar", Amesterdam, Oxford, New York, 1982, 156.

[10] Van der Poel, P. W.; Schiweck, H.; Schwarz, T. "Sugar Technology : Beet and Cane Sugar Manufacture", Verlag Dr. Albert Bartens KG, Berlin. 1998.

[11] Girgis, B. S.; Khalil, L. B.; Tawfik, T. A. M. Adsorp. Sci. Technol. 2000, 18, 373.

[12] Girgis, B. S.; EL-Hendawy, A. N. A. Micropor. Mesopor. Mats. 2002, 52, 105.

[13] Attia, A. A.; Girgis, B. S.; Khedr, S. A. J. Chem. Technol. Biotechnol. 2003, 78, 611.

[14] Attia, A. A.; Girgis, B. S.; Tawfik N. A. F., Carbon Sci. 2005, $6,1$.

[15] Kobya, M.; Demirbas, E.; Senlurk, E.; Ince, M. Bioresource Technol. 2005, 96, 1518.

[16] Wartelle, L. H.; Marshall, W. E. J. Chem. Technol. Biotechnol. 2001, 76, 451.

[17] Girgis, B. S.; Yunis, S. S.; Soliman, A. M. Materials Letts. 2002, 57, 146.

[18] Warhurst A. M.; McConnachie, G. L.; Pollard, S. J. T.
Water Res., 1997, 31, 757.

[19] Kalavathy, M. H.; Karthikeyan, T.; Rajgopal, S.; Miranda, R. J. Colloid Inter. Sci. 2005, 292, 354.

[20] de Celis, J.; Amadeo, N. E.; Cukierman, A. L. J. Hazard. Mats. 2009, 16, 217.

[21] Gomez-Serano, V.; Cuerde-Correa, E. M.; FernandezGonzalez, M. C.; Alexandre-Franco, M. F.; Macias-Garcia, A. Materials Letts. 2005, 59, 846.

[22] Girgis, B. S.; Smith, E.; Louis, M. M.; EL-Hendawy, A. N. A. J. Anal. Appl. Pyr. 2009, 86, 180.

[23] Guo, Y.; Yu, K.; Wang, Z.; Xu, H. Carbon 2000, 41, 1645.

[24] Rashwan, W. E.; Girgis, B. S. Adsorp. Sci. Technol. 2004, 22, 181.

[25] Marshall, W. E.; Ahmedna, M.; Rao, R. M.; Johns, M. M. Int. Sugar JNL 2000, 102, 147.

[26] Tseng, R.-L.; Tseng, S.-K. J. Coll. Interface Sci. 2005, 287, 428.

[27] Basso, M. C.; Cerella, E. G.; Cukierman, A. L. Ind. Eng. Chem. Res. 2002, 41, 180.

[28] Byrne, J. F.; Marsh, H. "Porosity in activated carbons", Ed. J.W. Patrick, Edward Arnold Inc., London, 1995.

[29] Puziy, A. M.; Poddubnaya, O. I.; Martinez-Alonso, A.; Suarez-Garcia, F.; Tascon,J. M. D. Appl. Surf. Sci. 2002, 200, 196.

[30] Puziy, A. M.; Poddubnaya, O. I.; Martinez-Alonso, A.; Suarez-Gorcia, F.; Tascon, J. M. D. Carbon 2005, 43, 2857.

[31] IUPAC Pure \& Appl. Chem. 1994, 66, 1739.

[32] Selles-Perez, M. J.; Martin-Martinez, J. M. J. Chem. Soc. Faraday Trans. 1991, 87, 1237. 